\title{
Evaluating the Effect of Root Cohesion on Shallow Landslides for Physically Based Modeling
}

\author{
Su-Jin Jang, ${ }^{1}$ Suk Woo Kim, ${ }^{1,2 *}$ Minseok Kim, ${ }^{3}$ and Kun-Woo Chun ${ }^{2 * *}$ \\ ${ }^{1}$ Institute of Forest Science, Kangwon National University, \\ 1, Kangwondaehak-gil, Chuncheon 24341, Republic of Korea \\ ${ }^{2}$ Division of Forest Science, College of Forest and Environmental Sciences, Kangwon National University, \\ 1, Kangwondaehak-gil, Chuncheon 24341, Republic of Korea \\ ${ }^{3}$ Geologic Environment Division, Korea Institute of Geoscience and Mineral Resources, \\ 124, Gwahak-ro, Yuseong-gu, Daejeon 34132, Republic of Korea
}

(Received August 29, 2021; accepted November 2, 2021)

Keywords: shallow landsides, SHALSTAB modeling, hillslope stability, root cohesion, ROC

In physically based landslide modeling, to improve the accuracy of source area prediction, it is important to not only use high-resolution terrain information but also apply field-based soil properties. The objective of this study was to use physically based models to evaluate the effect of root cohesion, which may have influenced slope instability and the occurrence of shallow landslides in a forested basin located in Saam-ri, Chuncheon, South Korea. The shallow landsliding stability (SHALSTAB) model used in this study was applied to three scenarios with different soil and root cohesion. In scenarios $1(1 \mathrm{kPa})$ and $2(2 \mathrm{kPa}), 15.0$ and $4.7 \%$ of the entire basin were classified as unstable (factor of safety $(F S)<1.0$ for the critical rainfall of $151 \mathrm{~mm}$ day $\left.^{-1}\right)$, whereas in scenario $3(2-20 \mathrm{kPa})$, where soil and root cohesion input was interpolated and rasterized spatially, only $4.3 \%$ of the entire basin was classified as unstable. The accuracy and precision of each scenario were evaluated using receiver operating characteristic (ROC) analysis. The area under the curve (AUC), accuracy, and precision in scenario 3 were $0.858,96.4 \%$, and $32.1 \%$, respectively, which were higher than those in scenarios 1 and 2 . These results demonstrate the incorporation of spatial analysis of soil and root cohesion in determining the effect of root reinforcement in the SHALSTAB model. Thus, field-surveyed cohesion data and their interpolation can be applied to improve the accuracy and precision of the predictive simulation of shallow landslides.

\section{Introduction}

Landslides in mountainous regions induced by heavy rain can cause significant damage to human livelihoods. The occurrence of landslides is affected by various factors such as topography, geological features, soil depth, and cohesion (including root cohesion). ${ }^{(1-4)}$ Most landslides in Korea are failures of shallow soil layers within a depth of $2.0 \mathrm{~m}$; ${ }^{(5-7)}$ debris flow generated by translational landslides is the primary cause of sediment-related disasters. As

*Corresponding author: e-mail: kimsw@kangwon.ac.kr

${ }^{* *}$ Corresponding author: e-mail: kwchun@kangwon.ac.kr

https://doi.org/10.18494/SAM.2021.3606 
described in many studies, shallow landslides can be caused by various factors, especially as shown in recent studies on the tree root distribution, where vegetation roots were shown to have a growth limit of 2-3 m depth. ${ }^{(8,9)}$ The limit of tree root growth is closely related to the soil layer (primarily the layer of soil above bedrock), which is affected by the geological structure. ${ }^{(8,9)}$ Therefore, as the root system of trees is distributed in the spatial range where shallow landslides occur (disintegration of the sloping plane), ${ }^{(10)}$ it is closely related to slope stability and collapse occurrence. In other words, when the roots of trees growing on a slope receive disintegration energy, the surface soil layer moves and deforms, and when the tensile resistance of the roots acts in the direction of the bedrock, the shear resistance of the soil increases, which acts in the opposite direction of the force. ${ }^{(11,12)}$ Ultimately, the greater the tensile resistance (tensile strength) of the tree roots, the greater the soil shear resistance (shear strength), which increases slope stability. ${ }^{(12-19)}$ Therefore, the effect of root reinforcement ${ }^{(11,20)}$ has been commonly recognized as a typical feature of trees in preventing surface collapse. ${ }^{(10)}$

Methods of evaluating the role of trees in slope stability and/or landslide prevention include not only direct measurement of the tensile resistance of tree roots ${ }^{(11,12,21,22)}$ but also a method that uses the soil shear resistance, which is the increased value of soil cohesion, as root cohesion for calculation. ${ }^{(10)}$ Additionally, because of the difficulty of directly measuring the tensile resistance of roots, it is estimated using previously reported data. ${ }^{(23,24)}$ However, in several studies, soil cohesion values of $0 \mathrm{kPa},{ }^{(25)} 1 \mathrm{kPa},{ }^{(26)}$ and $1.5 \mathrm{kPa}^{(27,28)}$ have been used to represent tree root reinforcement, which were not appropriate for evaluating features preventing surface collapse. In fact, trees growing on a forested hillslope show different spatial distributions of root depth, top-root ratio, root density, and mass according to the species. Therefore, because tensile resistance varies depending on the species, ${ }^{(11,21,29)}$ tree root reinforcement needs to be evaluated separately on the basis of tree species. To this end, it is necessary to obtain root tensile resistance data from field tests or by estimation from the spatial distribution data (i.e., depth, mass, and diameter) of the root system. ${ }^{(30)}$ However, there are limitations in establishing an entire dataset for each species through field investigation. Thus, in recent studies, a method of calculating root cohesion by considering the crown density based on aerial photograph analysis and field investigation has been proposed, in which the effect of root cohesion on the slope safety factor was assessed using an infinite slope stability model. ${ }^{(31)}$ To improve the predictive accuracy of landslide susceptibility in physically based landslide modeling, it is important to not only use high-resolution terrain information but also apply field-based soil properties. When applying field-surveyed data of soil properties, it should be examined thoroughly whether they reflect the characteristics of each tree species, especially from the ecosystem service perspective of the forest, and lead to accurate location prediction of landslide sources in mountainous areas.

Various models [transient rainfall infiltration and grid-based regional slope stability (TRIGRS), stability index mapping (SINMAP), and shallow landslide instability prediction (SLIP) models] ${ }^{(32,33)}$ have been used for landslide susceptibility assessment and prediction. However, methods such as TRIGRS that calculate the watershed using one value (a singlelayered, homogenous soil cover) ${ }^{(34)}$ appear to have limitations in assessing the impact of trees. Thus, in this study, we used the steady-state condition shallow landsliding stability (SHALSTAB) model developed by Dietrich and Montgomery to consider the topography, because it is 
internationally recognized as a model that can consider the spatial characteristics of the forest type (spatial distribution data cell by cell) and topography. ${ }^{(35)}$

For the SHALSTAB model, we simulated shallow landslides using soil and root cohesion, including (1) the cohesion of the soil itself and (2) the root cohesion of each forest type. We also evaluated the effect of tree root cohesion for different forest types on the accuracy of the landslide occurrence simulation by comparison with aerial photographs and verification through a receiver operating characteristic (ROC) analysis after a landslide disaster.

\section{Materials and Methods}

\subsection{Study site}

The study site was located in a forested basin in Saam-ri, Chuncheon, South Korea $\left(37^{\circ} 49^{\prime} 21.2^{\prime \prime} \mathrm{N}, 127^{\circ} 47^{\prime} 03.2^{\prime \prime} \mathrm{E}\right)$ (Fig. 1). The basin area was $0.34 \mathrm{~km}^{2}$, and the elevation in this region ranged from 99.0 to $675.1 \mathrm{~m}$ above sea level. The channel was $1150 \mathrm{~m}$ in length and had a slope of $13.2^{\circ}$. Gneiss (i.e., biotite/banded gneiss) was identified as the representative geology, and residence soil and colluvial soil appeared in the ridge and mountain foot areas, respectively.

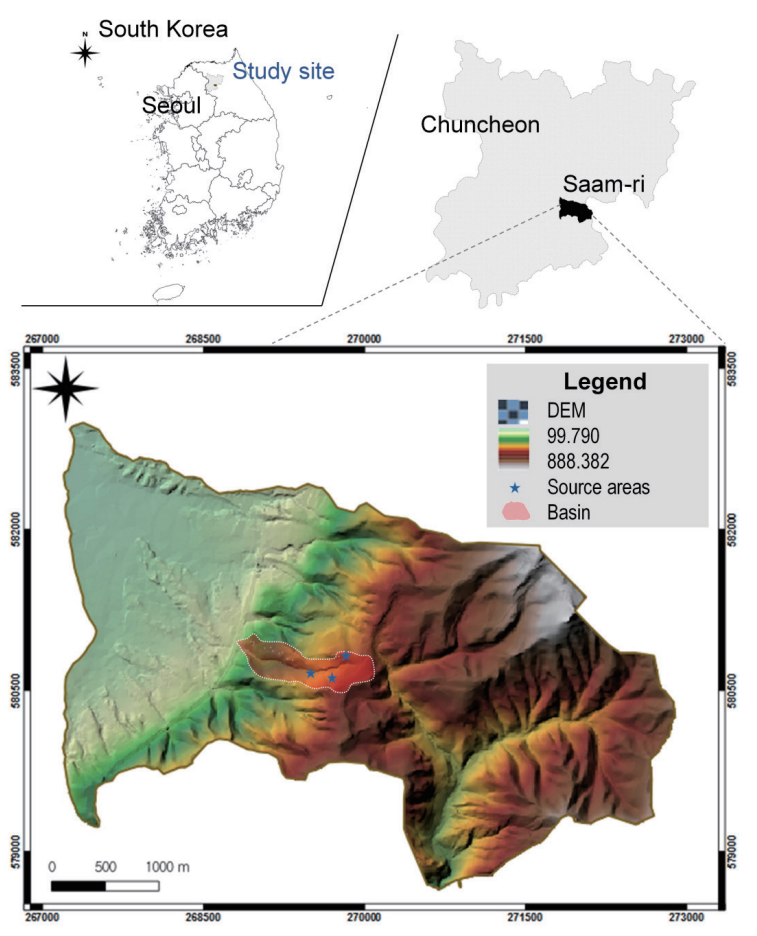

(a)

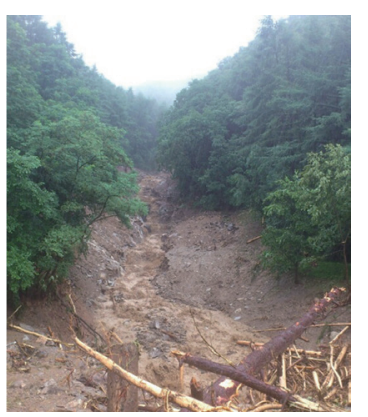

(b)

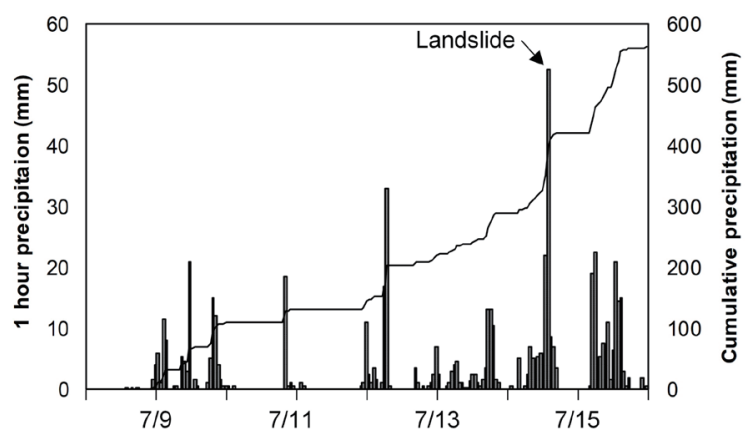

(d)

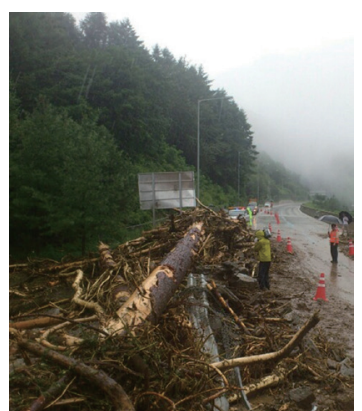

(c)

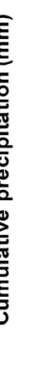

敦


Additionally, $84.6 \%$ of the basin was covered by coniferous trees, such as Larix kaempferi (69.1\%, 23.4 ha), Pinus densiflora and Pinus rigida (14.6\%, 4.9 ha), and Pinus koraiensis (0.9\%, $0.3 \mathrm{ha}$ ), 5.3\% (1.8 ha) was covered by deciduous broad-leaved trees, such as Quercus spp., and $10.1 \%$ (3.4 ha) was covered by mixed stands. The species composition, tree number, diameter at breast height, tree age, and crown density for each forest type are summarized in Table 1.

In this study site, a sediment-related disaster (shallow landslide and debris flow) occurred at 09:06 on July 14, 2013. It started from a shallow landslide of a filled slope on the forest road, and debris flowed downstream within the headwater catchment. The rain gauge (Chuncheon weather station) recorded $402 \mathrm{~mm}$ cumulative rainfall from 15:00 on July 07 to 09:00 on July 14, and a maximum intensity of $52.5 \mathrm{~mm} \mathrm{~h}^{-1}$ at the time of occurrence (08:00-09:00 on July 14). This event resulted in forest degradation of 5.67 ha and destroyed road facilities including guard rails and retaining walls near the Chuncheon tollgate on the Jungang expressway.

\subsection{Model description}

The root reinforcement model proposed by Waldron in 1977 [Eq. (1)] was used to calculate the soil shear resistance generated by the tensile resistance of the roots (i.e., the effect of tree roots on soil reinforcement), which is applied in the opposite direction from the force that induces shear failure of the soil. ${ }^{(36)}$

$$
\tau=\sigma \tan \phi+C+\Delta C
$$

Here, $\tau$ is the soil shear resistance $(\mathrm{kPa}), \sigma$ is the normal stress on the shear plane $(\mathrm{kPa}), \phi$ is the internal friction angle of the soil (degrees), $C$ is the soil cohesion $(\mathrm{kPa})$, and $\Delta C$ is increase in soil cohesion provided by the roots $(\mathrm{kPa})$.

The infinite slope stability model is commonly utilized to predict shallow landslide areas because it reflects topographical characteristics and soil properties. The basic premise of this

Table 1

Structural characteristics for each forest type in the study site.

\begin{tabular}{|c|c|c|c|c|c|}
\hline Forest type & Species & $\begin{array}{l}\text { Tree number } \\
\left(\text { trees } 100 \mathrm{~m}^{-2} \text { ) }\right.\end{array}$ & $\begin{array}{l}\text { Diameter at breast } \\
\text { height }^{\mathrm{a}}(\mathrm{cm})\end{array}$ & $\begin{array}{l}\text { Tree age }^{b} \\
\text { (year) }\end{array}$ & $\begin{array}{c}\text { Crown density } \\
(\%)\end{array}$ \\
\hline Korean white pine & Pinus koraiensis & $5-6$ & $20.5 \pm 2.2^{\mathrm{c}}$ & $30-40$ & $\geq 70$ \\
\hline Mixed & $\begin{array}{c}\text { Quercus spp. } \\
\text { Prunus serrulata } \\
\text { Betula davurica } \\
\text { Pinus densiflora } \\
\text { Pinus rigida }\end{array}$ & $6-13$ & $20.9 \pm 5.4$ & $30-40$ & $\geq 70$ \\
\hline $\begin{array}{l}\text { Korean red pine/ } \\
\text { Pitch pine }\end{array}$ & $\begin{array}{l}\text { Pinus densiflora } \\
\text { Pinus rigida }\end{array}$ & $5-8$ & $28.4 \pm 3.6$ & $20-50$ & $\geq 70$ \\
\hline Oak & $\begin{array}{l}\text { Quercus mongolica } \\
\text { Quercus variabilis }\end{array}$ & $7-13$ & $14.1 \pm 1.2$ & $30-40$ & $\geq 70$ \\
\hline Japanese larch & Larix kaempferi & $6-8$ & $23.7 \pm 2.7$ & $30-40$ & $\geq 70$ \\
\hline
\end{tabular}

${ }^{a}$ Measured in four $10 \times 10 \mathrm{~m}$ survey plots for each forest type

${ }^{\mathrm{b}}$ Analyzed using 1:5000 scale forest type map provided by the Korea Forest Service

${ }^{\mathrm{c}}$ Mean \pm standard deviation 
concept is that the surface soil moves parallel to the bedrock surface under the collapse force. The factor of safety $(F S)$, expressed by Eq. (2), is the ratio of the resisting force to the driving force (destabilizing forces) on a slope. ${ }^{(32,37-40)}$ The slope is stable when $F S$ is greater than or equal to 1.0 and unstable when $F S$ is less than 1.0. ${ }^{(33)} F S$ can ultimately be expressed using Eq. (5) because the dimensionless relative wetness $W$ is defined as the saturation storage of the soil in the steady-state condition (i.e., rainfall and infiltration) [Eqs. (3) ${ }^{(41)}$ and (4)].

$$
\begin{gathered}
F S=\left[\cos \beta\left\{1-W\left(\rho_{w} \rho_{s}^{-1}\right)\right\} \tan \phi+C+\Delta C\right] \sin \beta^{-1}, \\
W=R_{c} a(b T \tan \beta)^{-1}, \\
W=h Z^{-1}, \\
F S=\sin \beta \cos \beta^{-1}\left\{1-\left(\rho_{w} h \rho_{s} Z^{-1}\right)\right\}\left(\tan \phi \tan \beta^{-1}\right)\left(C_{\text {total }} \rho_{s} Z^{-1}\right), \\
\left.R_{c}=T \sin \beta\left(b a^{-1}\right)\left(\rho_{w} \rho_{s}^{-1}\right)\left[1-\left\{(\sin \beta-C)(\cos \beta \tan \phi)^{-1}\right)\right\}\right] .
\end{gathered}
$$

Here, $\beta$ is the slope angle (degrees), $\rho_{s}$ is the density of saturated soil $\left(\mathrm{kg} \mathrm{m}^{-3}\right),{ }^{(42)} \rho_{w}$ is the density of water $\left(\mathrm{kg} \mathrm{m}^{-3}\right), \phi$ is the internal friction angle of the soil (degrees), $C$ is the soil cohesion (dimensionless cohesion) $\left(\mathrm{N} \mathrm{m}^{-2}\right), \Delta C$ is the increase in soil cohesion provided by the roots $\left(\mathrm{N} \mathrm{m}^{-2}\right), R_{c}$ is the critical rainfall necessary to trigger landslides $\left(\mathrm{mm} \mathrm{h}^{-1}\right), T$ is the saturated soil transmissivity $\left(\mathrm{m}^{2} \mathrm{~h}^{-1}\right), a$ is the upslope contributing area $\left(\mathrm{m}^{2} \mathrm{~m}^{-1}\right), b$ is the unit contour length (m), $h$ is the vertical height of the water table, and $z$ is the vertical soil thickness (m).

\subsection{Conceptual framework of study}

The procedure used to determine the effect of tree root cohesion on shallow landslides is shown in Fig. 2. First, geological, topographical, heavy rainfall, and disaster history data were collected through an indoor survey of the designated sites. The DEM was prepared, and the topography was examined using 1:5000 scale digital topographic maps provided by the National Geographic Information Institute in Korea, and hydrological analysis of the flow direction and accumulation (single flow) was conducted using ArcGIS 10.1. The field cohesion survey (i.e., field vane test) and laboratory soil test (i.e., direct shear test) were conducted to determine the input parameters required for the SHALSTAB model for evaluating the effect of tree root cohesion. On this basis, the SHALSTAB simulation was conducted to estimate the source of shallow landslides. Finally, the simulation results were compared with aerial photographs after the disaster.

\subsection{Data collection and field sampling}

Soil shear strength is commonly described as a term of soil cohesion, and the increase in shear strength caused by the root tensile strength can be regarded as root cohesion. ${ }^{(43)}$ The input 


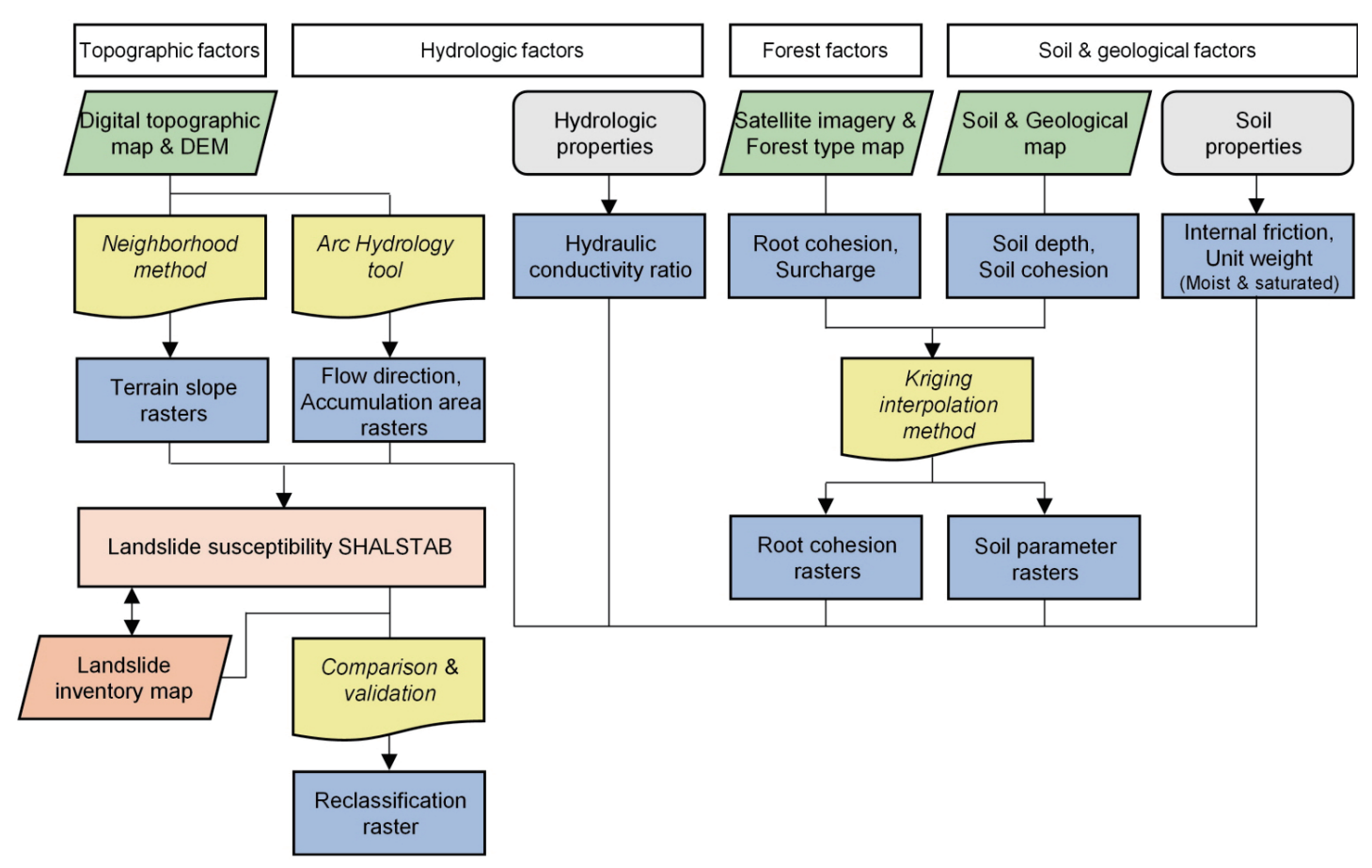

Fig. 2. (Color online) Conceptual framework of the study.

parameter for the SHALSTAB model simulation in this study was the minimum shear strength obtained from a field vane test (Fig. 3). The residual shear strength was applied, assuming that the soil was $100 \%$ saturated by heavy rainfall. However, in forests, a $20 \mathrm{~cm}$ depth value was used, taking into consideration the fact that the effect of root reinforcement on shallow landslides should be studied at a depth of $0-20 \mathrm{~cm}$, where tree roots are mainly present, rather than 0-10 cm depth. ${ }^{(11)}$ Alternatively, a direct shear test was conducted using undisturbed soil samples collected near the field vane test site, and reliability was evaluated by comparing the results of the two tests.

\subsection{Scenario design and data interpolation}

Groundwater is located on the boundary between the soil layer, including the topsoil, and the underlying bedrock layer in the following scenario, and it was assumed that the soil is saturated. A cohesion value of $1 \mathrm{kPa}$ was applied as a representative value in scenario 1 , the minimum cohesion value ( $2 \mathrm{kPa}$ ) from the field survey results was applied as a representative value in scenario 2, and the field-surveyed soil and root cohesion (2-20 kPa) were applied according to the location in scenario 3.

The SHALSTAB simulation was conducted using a 5-m-resolution DEM derived from the 1:5000 scale digital topographic maps. The detailed input parameters for all the scenarios are shown in Table 2. The saturation unit weight and the angle of internal friction reflected the results of a direct shear test in Korean red pine ( $P$. densiflora) forest. Different values were only used for cohesion $C$. In scenario 3, field-surveyed cohesion according to the location was 


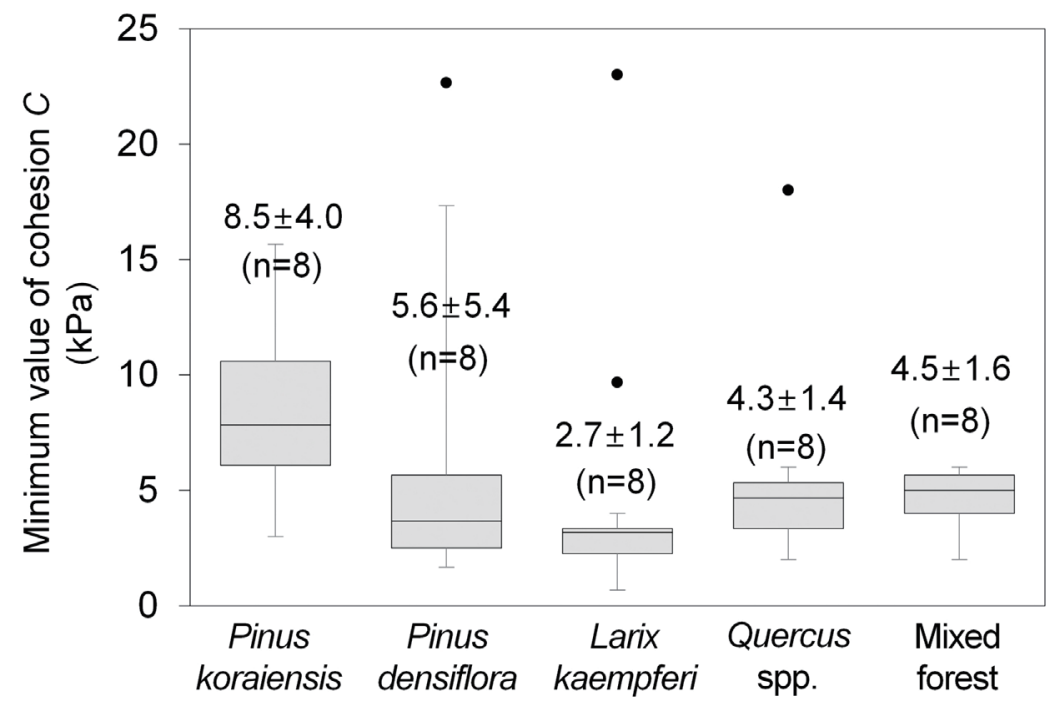

Fig. 3. Boxplot representations of the median (thick black line), upper and lower quartiles (box), 1.5 interquartile ranges (whiskers), and outliers (black dots outside whiskers) for selected cohesion data from field survey and sampling. Values above each box indicate mean \pm standard deviation.

Table 2

Hydraulic and geotechnical parameters of the study site.

\begin{tabular}{lccc}
\hline Input parameter & Scenario 1 & Scenario 2 & Scenario 3 \\
\hline Soil thickness $z(\mathrm{~m})$ & 1 & 1 & 1 \\
\hline Saturated unit weight $\left(\mathrm{kg} \mathrm{m}^{-3}\right)$ & 1620 & 1620 & 1620 \\
\hline Permeability coefficient $\left(\mathrm{m} \mathrm{day}^{-1}\right)$ & 40 & 40 & 40 \\
\hline Soil and root cohesion $(\mathrm{kPa})$ & 1 & 2 & $\begin{array}{c}2-20 \\
\text { (Kriging interpolation } \\
\text { method) }\end{array}$ \\
\hline Internal friction angle (degrees) & 38 & 38 & 38 \\
\hline
\end{tabular}

calculated and inputted into the data in the form of an interpolated raster using the kriging technique. Kriging is a statistical estimation method that interpolates data with a spatial distribution. Thus, the result of kriging reflected not only the distance from the measured value, but also the correlation between values measured in the surroundings. Previous studies have shown that kriging yields better estimations of altitude (height) than different interpolation methods, such as inverse distance weighting, nearest neighbor, and spline methods. ${ }^{(44,45)}$

\subsection{Assessment of the predictive accuracy}

The accuracy evaluation of landslide prediction analysis is very important. Many researchers ${ }^{(1,4,33,46,47)}$ have calculated the reliability of their models using ROC analysis. In this study, the prediction accuracy was evaluated using ROC analysis as follows: if an unstable grid cell was coincident with a landslide, it was counted as a true positive; if an unstable grid cell fell outside a landslide point, it was counted as a false positive; if a stable grid cell was coincident 
with a non-landslide point, it was counted as a true negative; if a stable grid cell fell outside a non-landslide point, it was counted as a false negative. ${ }^{(1)}$ ROC curves were plotted using the true positive rate (TPR) and false positive rate (FPR).

\section{Results}

\subsection{Characteristics of soil cohesion due to root reinforcement}

As described in Sect. 2.4, the mean values (minimum to maximum values) of the minimum shear strength measured from the soil of each forest type were $8.5 \mathrm{kPa}(4.7-16.2 \mathrm{kPa})$ for Korean white pine (e.g., P. koraiensis) forest, $5.6 \mathrm{kPa}(2.8-20.0 \mathrm{kPa})$ for Korean red pine forest, $4.5 \mathrm{kPa}$ $(3.7-5.2 \mathrm{kPa})$ for mixed forest, $4.3 \mathrm{kPa}(2.7-11.3 \mathrm{kPa})$ for oak (e.g., Quercus spp.) forest, and $2.7 \mathrm{kPa}(2.0-13.0 \mathrm{kPa})$ for Japanese larch (e.g., L. kaempferi) forest.

Meanwhile, the other input parameters were determined on the basis of the data measured by the direct shear test, because the cohesion $(16 \mathrm{kPa})$ at the sampling site (Korean red pine forest) was similar to the range of the field vane test results $(5.3-17.3 \mathrm{kPa})$ at the same site. As such, we confirmed that the increase in soil cohesion due to root reinforcement depended on the forest type.

\subsection{Comparison of critical rainfall and landslide source areas based on scenarios 1 to 3}

The steady-state critical rainfall likely to trigger landslides in the study area was calculated to be in the range of 293.5-373.5 mm day ${ }^{-1}$. For scenarios 1 to 3, it was $293.5,356.5$, and $373.5 \mathrm{~mm}$ day $^{-1}$, respectively. These values were much larger than the actual amount (i.e., $151 \mathrm{~mm}$ day $^{-1}$ ) of rainfall that triggered landslides in the study area.

The examination of the source of shallow landslides using aerial photographs after the disaster identified a steep drop-off below the ridge, lateral erosion on both stream banks, sinuous channels, and the cutting slope of the forest trail. A total area of $8350 \mathrm{~m}^{2}(2.5 \%)$ was extracted as the landslide area (Table 3).

The results of the SHALSTAB model simulation for each scenario with a critical rainfall of $151 \mathrm{~mm}$ day $^{-1}$ are shown in Table 4. In scenario 1, the unstable land comprised $15.0 \%\left(50650 \mathrm{~m}^{2}\right)$ of the basin. In scenario $2,4.7 \%\left(15775 \mathrm{~m}^{2}\right)$ of the basin was identified as unstable land. In scenario 3, which was simulated with the minimum values of cohesion $(C+\Delta C)$ surveyed, unstable land covered $4.3 \%\left(14400 \mathrm{~m}^{2}\right)$ of the basin. The predicted area in each scenario was approximately $6.1,1.9$, and 1.7 times larger than the actual measured area. However, as the

Table 3

Source areas measured in study site using an aerial photograph in 2014.

\begin{tabular}{lcc}
\hline \multirow{2}{*}{ Categories } & \multicolumn{2}{c}{ Measured data } \\
\cline { 2 - 3 } & $(\%)$ & $\left(\mathrm{m}^{2}\right)$ \\
\hline Landslide & 2.5 & 8350 \\
\hline Non-landslide & 97.5 & 32625 \\
\hline
\end{tabular}


Table 4

Source areas estimated for each scenario under the critical rainfall $\left(151 \mathrm{~mm} \mathrm{day}^{-1}\right)$ necessary to trigger a landslide.

\begin{tabular}{lcccccc}
\hline \multirow{2}{*}{ Category } & \multicolumn{2}{c}{ Scenario 1 } & \multicolumn{2}{c}{ Scenario 2 } & \multicolumn{2}{c}{ Scenario 3 } \\
\cline { 2 - 7 } & $(\%)$ & $\left(\mathrm{m}^{2}\right)$ & $(\%)$ & $\left(\mathrm{m}^{2}\right)$ & $(\%)$ & $\left(\mathrm{m}^{2}\right)$ \\
\hline Unstable land & 15.0 & 50650 & 4.7 & 15775 & 4.3 & 14400 \\
\hline Stable land & 85.0 & 287325 & 95.3 & 322200 & 95.7 & 323575 \\
\hline
\end{tabular}

cohesion increased, the area of unstable land decreased (scenario $1>$ scenario 2), and the area of unstable land also decreased when the field survey results were applied by location rather than a blanket application (scenarios 1 and $2>$ scenario 3). The results of the SHALSTAB model simulation for each scenario are shown in Fig. 4. Under the conditions $>0$ and $\leq 50 \mathrm{~mm} \mathrm{day}^{-1}$ for scenario 1 , as well as $>0$ and $\leq 100 \mathrm{~mm} \mathrm{day}^{-1}$ for scenarios 2 and 3, it was predicted that the collapse is likely to expand at the gully and the curved channel, showing a potential sediment runoff downstream.

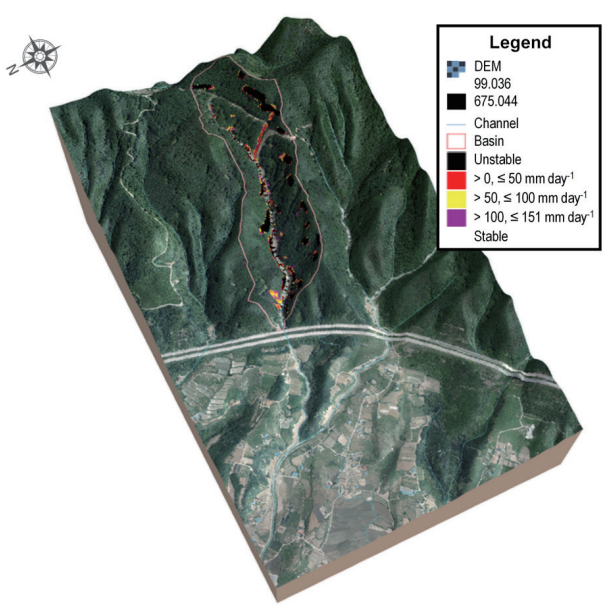

(a)

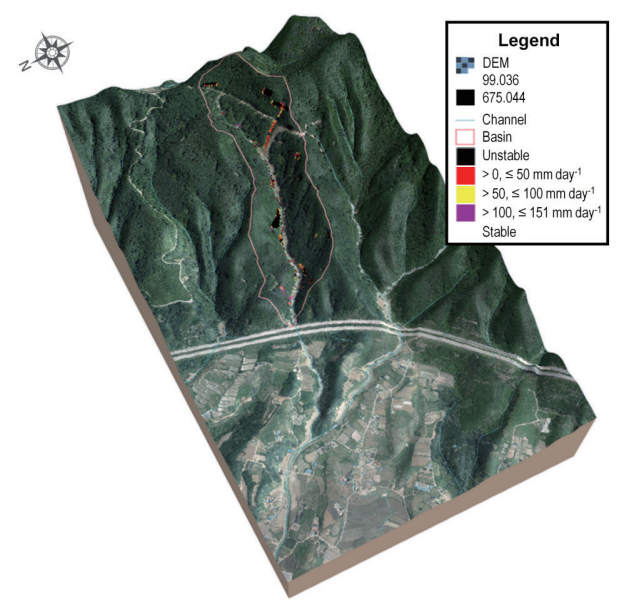

(b)

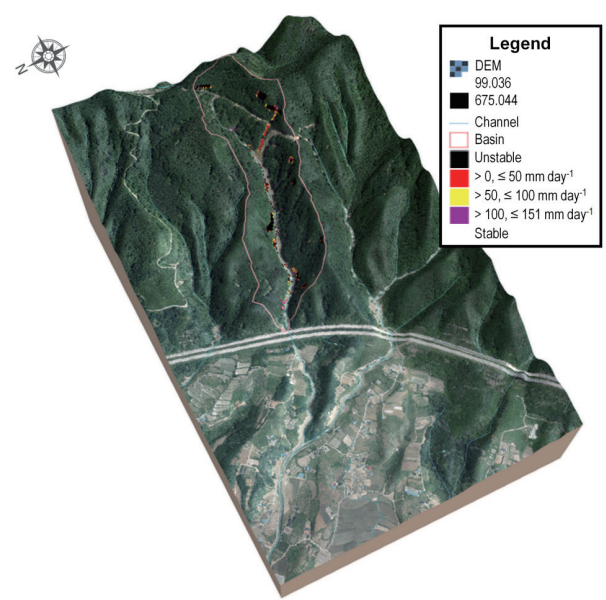

(c)

Fig. 4. (Color online) (a) Shallow landslide source area maps generated from SHALSTAB simulation in scenario 1, (b) scenario 2, and (c) scenario 3. The based map was captured by aerial photography in 2014. 
Figure 5(a) shows an aerial photograph taken before the 2013 heavy rainfall event. Because no orthoimages or aerial photographs had been established at the time of the disaster, the simulation results were superimposed with the background map obtained from the aerial photographs taken in 2014 [Fig. 5(b)]. On the basis of the location of the field survey results, the unstable land characterized by the critical rainfall of $151 \mathrm{~mm}$ day $^{-1}$ in scenario 3 slightly resembled the collapse range from the aerial photograph, but it was shown to have a smaller surface area [Figs. 5(b) and 5(c)].

\subsection{Assessment of the predictive accuracy based on ROC analysis}

As explained in Sect. 3.2, a ROC curve was computed for different thresholds (e.g., critical rainfall) of the $F S$ values in each scenario. The results of ROC analysis showed that TP and FP values were obtained at 221 points and 2179 points for scenario 1, 218 points and 1029 points for scenario 2, and 220 points and 1046 points for scenario 3, respectively. The area under the curve (AUC) values were found to be $0.804,0.855$, and 0.858 for scenarios 1 to 3 , respectively (Fig. 6). The AUC is widely used to estimate the predictive accuracy of prediction models (discrimination measures). In particular, prediction accuracy greater than or equal to 0.8 is considered very good.

The model accuracies of $89.9,96.2$, and $96.4 \%$ based on critical rainfall of $151 \mathrm{~mm}^{\text {day }}{ }^{-1}$ indicated that scenario 3 was effective for predicting the source of landslides (Table 5). The model precisions (i.e., positive predictive values) of $12.3,29.9$, and $32.1 \%$ also indicated that scenario 3 was effective. A lower rate of over-prediction yields estimates with much greater accuracy and precision. Similar concepts include the ratio of TPR to FPR, which is the ratio of the number of actual occurrence points predicted to be occurrence points divided by the number of actual non-occurrence points predicted to be non-occurrence points. ${ }^{(37)}$ The ratios of TPR to

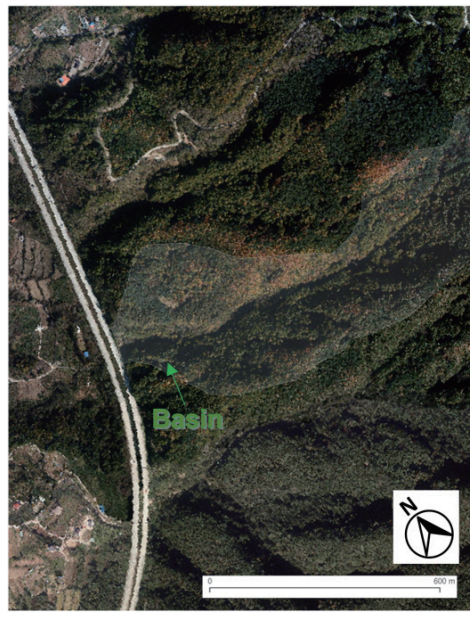

(a)

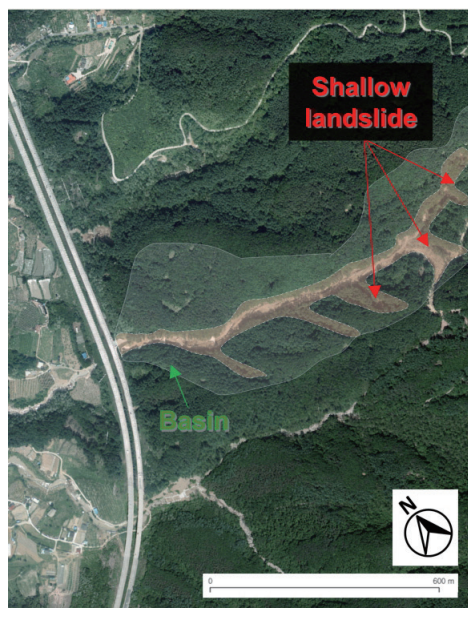

(b)

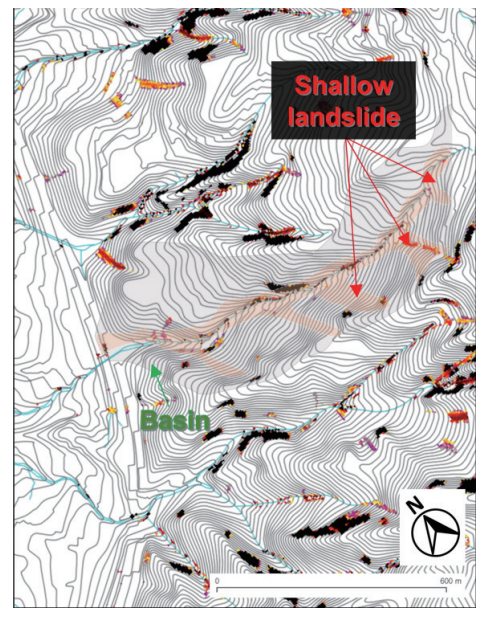

(c)

Fig. 5. (Color online) Comparison of (a) aerial photographs taken before and (b) after the 2013 heavy rainfall, and (c) SHALSTAB simulation results of scenario 3. 


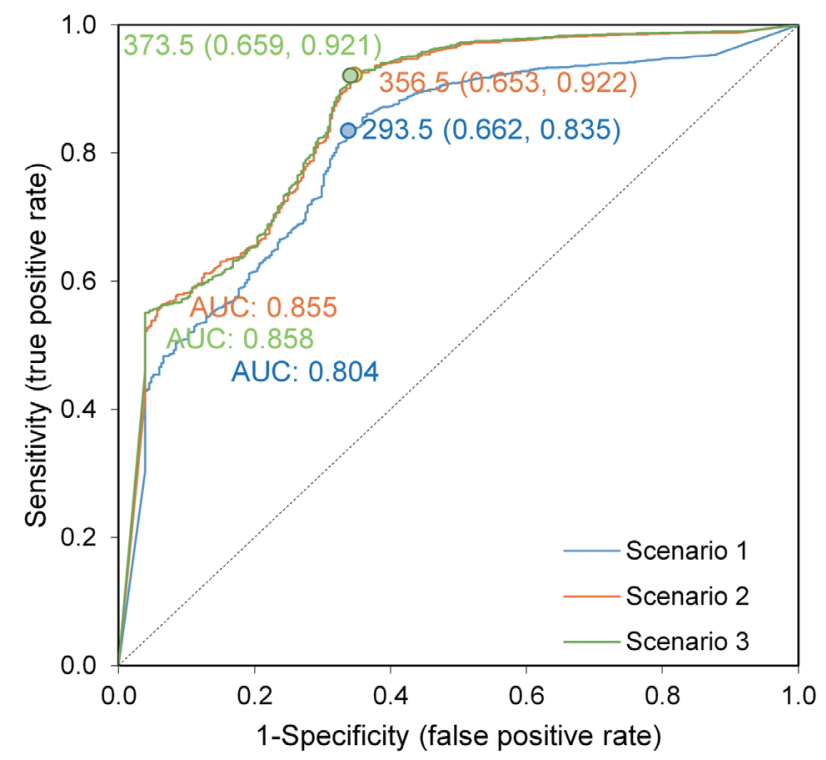

Fig. 6. (Color online) ROC curves derived from the estimated value in each scenario and the measured value. The dashed line shows the random classification of analysis results. The filled dots represent the calculated critical rainfall (i.e., 293.5, 356.5, and $373.5 \mathrm{~mm} \mathrm{day}^{-1}$ ) along the curves where $F S=1.0$.

Table 5

Results of ROC analysis based on critical rainfall of $151 \mathrm{~mm} \mathrm{day}^{-1}$.

\begin{tabular}{lccc}
\hline Category & Scenario 1 & Scenario 2 & Scenario 3 \\
\hline True positive rate (Sensitivity) & 0.500 & 0.404 & 0.401 \\
\hline False positive rate (1-Specificity) & 0.090 & 0.024 & 0.022 \\
\hline TPR FPR $^{-1}$ & 5.531 & 16.865 & 18.626 \\
\hline Accuracy & 0.899 & 0.962 & 0.964 \\
\hline Positive predictive value (Precision) & 0.123 & 0.299 & 0.321 \\
\hline Negative predictive value & 0.986 & 0.985 & 0.985 \\
\hline PPV + NPV & 1.109 & 1.284 & 1.305 \\
\hline
\end{tabular}

FPR were 5.531, 16.865, and 18.626 for scenarios 1 to 3, respectively, with the highest ratio in scenario 3 , for which the false positive rate was the lowest (0.022). Thus, the results of the predictive simulation were found to improve when the cohesion value according to the location was calculated and used, compared with the case of applying a single representative value of the cohesion value.

\section{Discussion}

Unlike the results of a previous study, ${ }^{(11)}$ those of this study showed that the soil cohesion due to root reinforcement was higher in coniferous forests than in broad-leaved forests (Fig. 3). Schmidt et al. ${ }^{(17)}$ showed that lateral root cohesion was higher in natural coniferous forests $(25.6-94.3 \mathrm{kPa})$ than in industrial deciduous forests $(6.8-23.2 \mathrm{kPa})$. These findings suggest that soil and root cohesion vary depending on not only the soil texture and moisture ${ }^{(7,48)}$ but also the 
type of soil and vegetation and the environment. ${ }^{(7,43,49,50)}$ Although it is difficult to discuss differences in soil and root cohesion because of regional variations in environmental conditions, the simulation results of this study demonstrated that the landslide susceptibility was affected by soil and root cohesion by the tree species in a given region (Fig. 3, Table 5).

In steep mountainous areas, landslides often occur on concave slopes due to repeated soil erosion and sediment accumulation resulting from the inflow of rainwater. ${ }^{(51)}$ Nevertheless, predicting the location of the source area of shallow landslides originating in mountainous regions remains an important task. ${ }^{(23,24,52)}$ Various physical-based models, such as the SHALSTAB model, have been developed, and various analysis techniques have been used to verify the accuracy of the model. On the basis of the prediction of the critical rainfall using the SHALSTAB simulation results, the landslide susceptibility can be determined by calculating the optimal cut-off point using the Youden index. ${ }^{(53)}$ Many researchers have also used ROC analysis to categorize risk classes for landslide hazard maps. ${ }^{(33,38,46,47)}$ In this study, the cut-off point of the Youden index was determined to be higher than the actual generated daily rainfall, which appeared to be due to a limitation of this method in determining the positive discriminant standard and the optimal likelihood. In addition, the importance of preceding precipitation may need to be considered because, in the SHALSTAB model, it is evaluated from the daily rainfall rather than the cumulative rainfall.

The AUC of the ROC curve in Fig. 6 and the accuracy based on the critical rainfall of $151 \mathrm{~mm}$ day $^{-1}$ showed high values in all scenarios, but there was no significant difference between scenarios 2 and 3. Information on spatial variability in soil properties related to slope stability is vital but limited because it is seldom verified in case studies. ${ }^{(28,54)}$ Even in this study, it was difficult to secure large amounts of accurate data from the field sampling. Nevertheless, the simulation results of scenario 3 in this study can be considered to be relatively good. This is because the predicted rate of actual occurrence points based on the critical rainfall of $151 \mathrm{~mm}$ day $^{-1}$ divided by the predicted rate of non-occurrence points, namely, the ratio of TPR to FPR, was higher in scenario 3 than in scenario 2 (Table 5). In the future, the method based on scenario 3 in this study should be further tested, since it remains uncertain how to apply soil properties determined in laboratory tests to the optimum representative values for landscape-scale simulations. ${ }^{(28)}$

Generally, slope stability models estimate cohesion by extrapolating from an average or uniform distribution of point values. Accurate assessment of soil cohesion is important because it is the simplest and most important factor for soil maintenance. ${ }^{(37)}$ Investigation of differences in soil cohesion values according to tree growth and tree species can help to understand potential changes in landslides without a priori knowledge of the rooting strengths and distributions. ${ }^{(55)}$ At this point, the simulation results of this model could be used to identify the effect of changes in vegetation on slope stability. Note that the result of a model reflecting land-use changes, such as the removal (i.e., logging) of individual species in simple forests, is likely to be sensitive to slope stability. ${ }^{(55)}$

This study presents a method for reproducing the spatial distribution and securing the spatial representation of soil cohesion and its applicability to forested hillslopes through the use of a probabilistic modeling approach based on field data (i.e., kriging interpolation) to analyze 
landslide susceptibility. In particular, sampling and interpolation methods that rasterize a number of input parameters are expected to provide more detailed information for physically based modeling.

\section{Conclusions}

In this study, we applied the SHALSTAB model to predict the source area of shallow landslides using soil cohesion of $1 \mathrm{kPa}$ and using soil and root cohesion, including tree root cohesion obtained from a field survey, and we compared the results with aerial images taken after a landslide.

The results of a simulation based on the critical rainfall (i.e., $151 \mathrm{~mm}^{\text {day }}{ }^{-1}$ ) that triggered landslides showed that the area of unstable land decreased as the soil and root cohesion increased and also when the field survey results were applied according to the location rather than uniformly. According to the obtained ROC curve and AUC (0.858), the method based on scenario 3 was found to be suitable for predicting the source of shallow landslides with an accuracy of $96.4 \%$ and precision of $32.1 \%$, which were much higher than those in scenarios 1 and 2.

Although further tests are needed to fully verify the method proposed in this study, fieldsurveyed cohesion data and their interpolation can be applied to improve the accuracy and precision of predictive simulations of shallow landslides.

\section{Acknowledgments}

This study was supported by the Korean Ministry of Environment as part of the SS (Surface Soil Conservation and Management) projects (Project No. 2019002830002) and the R\&D Program for Forest Science Technology (Project No. 2021342B10-2123-CD01) of Korea Forest Service (Korea Forestry Promotion Institute).

\section{References}

1 J. W. Godt, R. L. Baum, W. Z. Savage, D. Salciarini, W. H. Schulz, and E. L. Harp: Eng. Geol. 102 (2008) 214. https://doi.org/10.1016/j.enggeo.2008.03.019

2 M. Borga, G. D. Fontana, and F. Cazorzi: J. Hydrol. 268 (2002) 56. https://doi.org/10.1016/S00221694(02)00118-X

3 M. Borga: Extreme Hydroclimatic Events and Multivariate Hazards in a Changing Environment: Hazard Assessment and Forecasting of Landslides and Debris Flows: A Case Study in Northern Italy (Elsevier, Amsterdam, 2019) pp. 343-367. https://doi.org/10.1016/B978-0-12-814899-0.00014-6

4 F. Cervi, M. Berti, L. Borgatti, F. Ronchetti, F. Manenti, and A. Corsini: Landslides 7 (2010) 433.

5 K. Choi: Landslide Occurrence and Its Prediction in Korea, Ph. D. Dissertation, Kangwon National University (1986) 1-45 (in Korean with English abstract). http://www.riss.kr/link?id=T2183282

6 K. Kim and Y. Song: J. Mt. Sci. 12 (2015) 1267. https://doi.org/10.1007/s11629-014-3108-Z

7 M. G. Persichillo, M. Bordoni, and C. Meisina: Sci. Total Environ. 574 (2017) 924. https://doi.org/10.1016/j. scitotenv.2016.09.125

8 T. Sammori: Shinrin Kagaku 47 (2006) 15 (in Japanese). https://doi.org/10.11519/jjsk.47.0_15

9 J. J. Roering, J. Marshall, A. M. Booth, M. Mort, and Q. Jin: Earth Planet. Sci. Lett. 298 (2010) 183. https://doi. org/10.1016/j.eps1.2010.07.040 
10 H. Imai: Technical Research Report of Hazama Corporation, Technical Research Institute of Hazama Corp. 40 (2008) 34-52 (in Japanese with English abstract). https://www.ad-hzm.co.jp/trr/hazama/2008/pdf_file/06.pdf

11 J. Oh, J. Hwang, and D. Cha: Kor. J. Env. Eco. 25 (2011) 31 (in Korean with English abstract). https://www.kci. go.kr/kciportal/ci/sereArticleSearch/ciSereArtiView.kci?sereArticleSearchBean.artiId=ART001534093

12 I. Lee, S. Sung, and C. Im: KSGE 7 (1991) 51 (in Korean with English abstract). https://www.koreascience. or.kr/article/JAKO199111920444211.page

13 T. Endo and T. Tsuruta: 1968 Annual Report of the Hokkaido Branch, Forest Experiment Station (1969) 167189.

14 M. G. Anderson and K. S. Richards: Slope Stability: Geotechnical Engineering and Geomorphology (John Wiley and Sons, Chichester, 1987).

15 N. J. Coppin and I. G. Richards: Use of Vegetation in Civil Engineering (Butterworths, London, 1990).

16 V. Operstein and S. Frydman: Ground Imp. 4 (2000) 81. https://doi.org/10.1680/grim.2000.4.2.81

17 K. M. Schmidt, J. J. Roering, J. D. Stock, W. E. Dietrich, D. R. Montgomery, and T. Schaub: Can. Geotech. J. 38 (2001) 995. https://www.proquest.com/docview/213473613?accountid=7411

18 L. P. H. van Beek, J. Wint, L. H. Cammeraat, and J. P. Edwards: Plant Soil 278 (2005) 55. https://doi. org/10.1007/s11104-005-7247-4

19 M. Genet, N. Kokutse, A. Stokes, T. Fourcaud, X. Cai, J. Ji, and S. Mickovski: For. Ecol. Manage. 256 (2008) 1517. https://doi.org/10.1016/j.foreco.2008.05.050

20 T. H. Wu, W. P. McKinnell, and D. N. Swanston: Can. Geotech. J. 16 (1979) 19. https://doi.org/10.1139/t79-003

21 D. S. Cha and B. Y. Ji: J. Korean For. Soc. 92 (2003) 33 (in Korean with English abstract). https://www.kci. go.kr/kciportal/ci/sereArticleSearch/ciSereArtiView.kci?sereArticleSearchBean.artiId=ART000877294

22 D. Kim, S. H. Lee, and S. Im: J. Korean Env. Res. Tech. 14 (2011) 41 (in Korean with English abstract). https:// www.kci.go.kr/kciportal/ci/sereArticleSearch/ciSereArtiView.kci?sereArticleSearchBean. artiId=ART001582085

23 E. Arnone, D. Caracciolo, L. V. Noto, F. Preti, and R. L. Bras: Water Resour. Res. 52 (2016) 8590. https://doi. org/10.1002/2015WR018227

24 A. Cislaghi, E. A. Chiaradia, and G. B. Bischetti: Earth Surf. Process. Landf. 42 (2017) 1789. https://doi. org/10.1002/esp. 4127

25 K. J. Chinnayakanahalli: An Objective Method for the Intercomparison of Terrain Stability Models and Incorporation of Parameter Uncertainty, Masters Dissertation, Utah State University (2004) 1-114. https:// www.proquest.com/docview/305104203?pq-origsite=gscholar\&fromopenview $=$ true

26 N. Kokutse, T. Fourcaud, K. Kokou, K. Neglo, and P. Lac: Proc. INTERPRAEVENT Int. Symp. Disaster Mitigation of Debris Flows, Slope Failures and Landslides (Japan Society of Erosion Control Engineering, Niigata, 2006) 561-567.

27 T. M. P. De Campos, M. H. N. Andrade, and E. A. Vargas Jr.: Proc. 6th Int. Symp. Landslides (Landslides, Christchurch, 1991) 1357-1364.

28 R. F. Guimarães, D. R. Montgomery, H. M. Greenberg, N. F. Fernandes, R. Gomes, and O. Abilio de CarvalhoJúnior: Eng. Geol. 69 (2003) 99. https://doi.org/10.1016/S0013-7952(02)00263-6

29 D. H. Gray and R. B. Sotir: Biotechnical and Soil Bioengineering Slope Stabilization: A Practical Guide for Erosion Control (John Wiley \& Sons, New York, 1996).

30 K. Abe, U. Kurokawa, and Y. Takeuchi: J. Jpn. Landslide Soc. 41 (2004) 225 (in Japanese with English abstract). https://doi.org/10.3313/jls.41.3_225

31 W. Choi, E. Choi, J. Suh, and S. Jeon: J. Korean Geosynth. Soc. 15 (2016) 13 (in Korean with English abstract). https://doi.org/10.12814/jkgss.2016.15.2.013

32 R. T. Pack, D. G. Tarboton, and C. N. Goodwin: Proc. 15th Annu. GIS Conf. (GIS, Vancouver, 2001) 19-22. https://igitalcommons.usu.edu/cee facpub/2578/

33 D. Zizioli, C. Meisina, R. Valentino, and L. Montrasio: Nat. Hazards Earth Syst. Sci. 13 (2013) 559. https://doi. org/10.5194/nhess-13-559-2013

34 F. Fusco, B. B. Mirus, R. L. Baum, D. Calcaterra, and P. De Vita: Water 13 (2021) 713. https://doi.org/10.3390/ w13050713

35 W. E. Dietrich and D. R. Montgomery: NCASI Tech. Rep. (1998) http://calm.geo.berkeley.edu/geomorph/ shalstab/index.htm

36 L. J. Waldron: Soil Sci. Soc. Am. J. 41 (1977) 843. https://doi.org/10.2136/sssaj1977.03615995004100050005x

37 M. Kim, J. K. Kim, Y. Cho, and S. Kim: JKGA 18 (2011) 193 (in Korean with English abstract). https://www. kci.go.kr/kciportal/ci/sereArticleSearch/ciSereArtiView.kci?sereArticleSearchBean.artiId=ART001624962

38 M. Kim, J. K. Kim, A. Jeong, and K. Jung: JKGA 22 (2015) 17 (in Korean with English abstract). https://doi. org//JKGA.22.3.17 
39 C. Bartelletti, G. D. Avanzi, Y. Galanti, R. Giannecchini, and A. Mazzali: Rend. Online Soc. Geol. It. 35 (2015) 17. https://doi.org/10.3301/ROL.2015.53

40 S. Kim, M. Kim, H. An, K. Chun, H. Oh, and Y. Onda: Catena 182 (2019) 1041347. https://doi.org/10.1016/j. catena.2019.104137

41 E. M. O’Loughlin: Water Resour. Res. 22 (1986) 794. https://doi.org/10.1029/WR022i005p00794

42 A. Talebi, R. Uijlenhoet, and P. A. Troch: Nat. Hazards Earth Syst. Sci. 7 (2007) 523. https://doi.org/10.5194/ nhess-7-523-2007

43 J. E. Norris, A. Stokes, S. B. Mickovski, E. Cammeraat, R. van Beek, B. C. Nicoll, and A. Achimeds: Slope Stability and Erosion Control: Ecotechnological Solutions (Springer, Netherlands, 2008) pp. 119-166. https:// link.springer.com/chapter/10.1007/978-1-4020-6676-4_5

44 D. Zimmerman, C. Pavlik, A. Ruggles, and M. P. Armstrong: Math. Geol. 31 (1999) 375. https://link.springer. com/content/pdf/10.1023/A:1007586507433.pdf

45 P. V. Arun: EJRS 16 (2013) 133. https://doi.org/10.1016/j.ejrs.2013.09.001

46 A. M. S. Pradhan and Y. T. Kim: Catena 140 (2016) 125. https://doi.org/10.1016/j.catena.2016.01.022

47 R. Senouci, N. Taibi, A. C. Teodoro, L. Duarte, H. Mansour, and R. Y. Meddah: Sustainability 13 (2021) 630. https://doi.org/10.3390/su13020630

48 M. Hosseini, S. A. R. Movahedi Naeini, A. A. Dehghani, and M. Zeraatpisheh: J. Soil Sci. Plant Nutr. 18 (2018) 939. https://doi.org/10.4067/S0718-95162018005002702

49 Y. H. Chok, M. B. Jaksa, W. S. Kaggwa, and D. V. Griffiths: IJGE 6 (2015) 12. https://doi.org/10.1186/s40703015-0012-5

50 M. J. Van De Wiel and S. E. Darby: Earth Surf. Process. Landf. 32 (2007) 2185. https://doi.org/10.1002/esp.1522

51 W. E. Dietrich and T. Dunne: ZfG Supplementband 29 (1978) 191. http://geomorphology.sese.asu.edu/Papers/ Dietrich_and_Dunne_1978.pdf

52 A. G. T. Temgoua, N. K. Kokutse, Z. Kavazović, and M. Richard: Ecol. Eng. 106 (2017) 609. https://doi. org/10.1016/j.ecoleng.2017.06.043

53 W. J. Youden: Cancer 3 (1950) 32. https://doi.org/10.1002/1097-0142(1950)3:1<32::aidcncr2820030106>3.0.co;2-3

54 A. Burton, T. Jh. Arkell, and J. C. Bathurst: Environ. Geol. 35 (1998) 100. https://link.springer.com/ article $/ 10.1007 \% 2 \mathrm{Fs} 002540050297$

55 T. C. Hales: Earth Surf. Process. Landf. 43 (2018) 2157. https://doi.org/10.1002/esp.4381

\section{About the Authors}

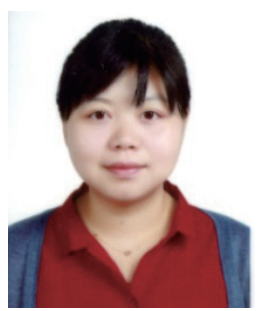

Su-Jin Jang received her B.S., M.S., and Ph.D. degrees from Kangwon National University, Republic of Korea, in 2008, 2010, and 2019, respectively. From 2014 to 2015, she was an associate researcher at the Research Institute for Gangwon, Republic of Korea. Since 2019, she has been a research fellow at the Institute of Forest Science, Kangwon National University, Republic of Korea. Her research interests are in landslides and physically based models. (sujinjang@kangwon.ac.kr)

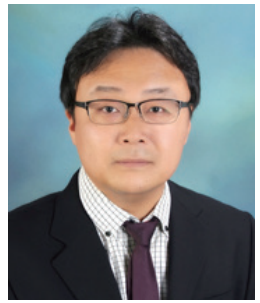

Suk Woo Kim received his B.S. and M.S. degrees from Kangwon National University, Republic of Korea, in 2003 and 2005, respectively, and his Ph.D. degree from Hokkaido University, Japan, in 2009. Since 2017, he has been an assistant professor at Kangwon National University. His research interests are in rainfall-triggered landslides, landslide modeling, and soil erosion.

(kimsw@kangwon.ac.kr) 


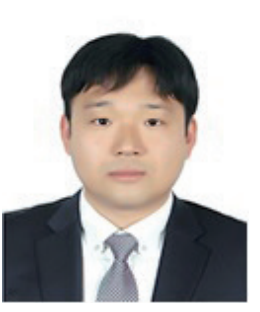

Minseok Kim received his B.S. and M.S. degrees from Chungnam National University, Republic of Korea, in 2004 and 2006, respectively, and his Ph.D. degree from the University of Tsukuba, Japan, in 2015. Since 2016, he has been a senior researcher at the Korea Institute of Geoscience and Mineral Resources. His research interests are in landslide experiments, sensor monitoring, and subsurface flow mechanisms. (minseok_kim@kigam.re.kr)

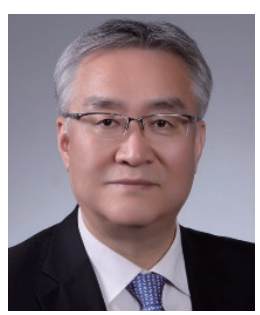

Kun-Woo Chun received his B.S. and M.S. degrees from Kangwon National University, Republic of Korea, in 1978 and 1980, respectively, and his Ph.D. degree in agriculture from Hokkaido University, Japan, in 1987. From 1987 to 2020, he was a professor at the Division of Forest Science, Kangwon National University, Republic of Korea. Since 2020, he has been an emeritus professor at Kangwon National University. His research interests are in erosion control, debris flow, and coastal sand dune fixation. (kwchun@kangwon.ac.kr) 